\title{
Is there a Namibian Afrikaans? Recent trends in grammatical variation in Afrikaans varieties within and across Namibia's borders
}

\author{
Gerald Stell \\ F. W. O. /V. U. B., Pleinlaan 2, B-1050 Brussels \\ E-mail: gstell@vub.ac.be
}

\section{Introduction}

There has been a tradition of treating geographical factors and social structures as distinct variables in research on language variation within single speech communities, and as a result their mode of interaction has not yet been theorized (Britain 2002). At which point geography, in its human and physical dimensions, precedes or follows social structures in the configuration of language variation seems to depend on two potentially related factors, i.e. the strength or weakness of social network ties, as well as the propensity of a given society to maintain ethnic divides. Of interest here is how far a recent political border can geographically disrupt formerly homogeneous patterns of language variation within a single, yet ethnically divided speech community, and, conversely, how far a range of social factors co-defined by ethnicity can ensure the maintenance of linguistic homogeneity irrespective of new political configurations of space.

Variation in Afrikaans has rarely been characterized in terms of the political border separating Namibia (formerly South West Africa or S.W.A.) and South Africa ever since Independence in 1990. Instead, the varieties spoken in S.W.A./Namibia have pretty much been regarded as a constellation of relocated South African varieties. It seems fair to assume that, up until Independence, these varieties had little sociolinguistic scope for diverging from their South African counterparts and that a state of continuum prevailed on account of greater freedom of movement across the border as well as similar degrees of exposure to prescriptive Standard Afrikaans through education.

The main question we want to answer here is how much potential for disruption of that continuum, if it prevailed at all, has been brought about by Namibia's political border and its sociolinguistic implications, and whether that potential warrants the use of the label "Namibian Afrikaans" in reference to the Afrikaans varieties spoken in Namibia.

To answer this question, a corpus of informal speech involving three distinct age cohorts of native White and Coloured/Baster ${ }^{1}$ Afrikaans speakers has been collected across the Namibian-South African border with a view of identifying patterns of variation in the realization of a set of grammatical variables. This paper is organized as follows: The first 
section gives a historical and sociolinguistic account of Cape Dutch and Afrikaans in the geographic zone covered by Namibia's current territory. This is followed by an overview of predictions on convergence and divergence between Afrikaans varieties across Namibia's borders that may seem justified by theoretical assumptions. After presenting the corpus, we will compare the diffusion of a few select grammatical features within and outside Namibia. Results confirming or disconfirming the idea of Namibian varieties of Afrikaans will be reviewed in the discussion.

\section{The origin and diffusion of Namibian Afrikaans varieties}

The present day territory of Namibia was until the late $18^{\text {th }}$ century thinly populated with Bantu-speaking tribes in the north and Khoi-San-speaking tribes in the south. From the late $18^{\text {th }}$ century onwards, Oorlam clans (groupings of partially Europeanized Khoi-Sans) from the Cape Colony introduced Cape Dutch in the territory. Parties of Basters (groupings of people with a common mixed European/Khoi-San origin) as well as isolated European Trekboere (transient pastoralists) also crossed the Orange River in the course of the $19^{\text {th }}$ century and thus strengthened the position of Cape Dutch, which rapidly spread as an oral and written lingua franca in the south and middle parts of the territory (cf. Marais 1962:98-99; Steyn 1980:125126; Stals and Ponelis 2001:71, 108). This situation endured under the German protectorate (1885-1915) as a result of the immigration of Boer refugees in the wake of the $2^{\text {nd }}$ Boer war. However, the language policy of the German colonial authorities resulted in increasing the diffusion of German among both Europeans and non-Europeans (Trümpelmann 1948:131132, 150; Steyn 1980:154-156).

The proclamation of the South African mandate in 1919 resulted in the officialization of Dutch/Afrikaans ${ }^{2}$ and English with German being granted special rights. While German retained its dominance in urban areas until WWII, the speaker base of Afrikaans was continually accrued through immigration from South Africa (cf. Ohly 1987:30; Beuke 1997:1-2) and Afrikaans-medium education was made compulsory in most of the territory (Niemand 1979:254-256). Ever since English became the sole official language of independent Namibia in 1991, the visibility of Afrikaans as a public language and a language of the media has radically diminished to a degree not yet paralleled in South Africa. It does however remain a supraregional and interethnic lingua franca in wide use, and it has often been retained as a primary level teaching medium in the southern regions (Beuke 1997).

The community which uses Afrikaans as first home language in Namibia has grown between 1991 and 2001 both in numbers (circa 126,000 in 1991 versus circa 201,000 in 2001) and share of the total population (9\% in 1991 versus $11 \%$ in 2001). Altogether $37.5 \%$ of Namibia's population was literate in Afrikaans in 2001 (Namibian Statistics 2001). Taking pre-Independence data as a frame of reference, the main population groups represented in Namibia's primary Afrikaans speech community are the so-called Whites, Coloureds and Basters $^{3}$. According to a survey conducted in 1970, 99\% of former South West Africa's Baster population spoke Afrikaans as a first home language, followed by the Coloureds (92\%) and Whites $(71 \%)$. Noteworthy is that a sizeable proportion of Basters/Coloureds claim to possess some knowledge of Nama/Damara (Combrink 1984:46; Maho 1998:157-158).

Nearly three quarters of the Afrikaans speech community is concentrated in the southern and central regions of Karas, Hardap, Erongo and Khomas. More than one fourth resides in the Windhoek region alone. Most of the Namibian Afrikaans speech community was urbanized 
by 1982: $85 \%$ of Whites lived in towns versus $82 \%$ of Coloureds and $62 \%$ of Basters. Nearly half of the country's Whites $(46.5 \%)$ lived in Windhoek versus $43.8 \%$ of the Coloureds and $34.7 \%$ of the Basters (van der Merwe 1983:47-49). Although not documented by current statistics, the economic gap which prevailed between Whites and non-Whites in general under the Apartheid may, in reflection of South African census data, be assumed not to have closed completely yet.

There has been no systematic attempt at classifying Namibian varieties of Afrikaans, which have so far been characterized only phonologically (van Schalkwyk and Odendal 1987) or lexically (Beuke 1997; Du Plessis 1985). Du Plessis (1987) includes Namibia's territory in the historical Orange River Afrikaans region (which also encompasses much of western South Africa) in acknowledgement of the Khoi-San substrate common to the Northern Cape and Southern Namibia, while mentioning the presence of other dialects, such as that spoken by the van der Merwes in the far north of Namibia. In addition to these varieties, Cluver (1992, in Beuke 1997) also mentions the presence of Southwestern Afrikaans varieties as well as the variety imported by White Afrikaans speakers from South Africa in the 1950s (which he refers to as "Standard Afrikaans" whereas others would probably use the label "Eastern Afrikaans", commonly applied to White varieties of Afrikaans ${ }^{4}$ ). Cluver's distinction suggests a linguistic gap between the White and non-White sectors of the Namibian Afrikaans speech community, with Eastern Afrikaans predominantly spoken among Whites and Orange River Afrikaans and Southwestern Afrikaans predominantly among non-Whites. Whereas this gap could have been consolidated as a result of the policies of residential and educational segregation imposed under the South African regime, the formerly high degree of exposure to prescriptive Standard Afrikaans ${ }^{5}$ through education across the ethnic divide in Namibia may not be overlooked as a potent factor of convergence between ethnic varieties of Afrikaans.

Taken together, historical data suggest that Namibian Afrikaans varieties are differentiated along ethnic lines and that they form part of ethnic dialect continua stretching across the border. One of these continua is the Orange River Afrikaans zone, which historically links parts of Namibia's Coloured population with Northern Cape Coloureds. The other continuum, which we tentatively refer to as "Eastern Afrikaans", is geographically less circumscribed as it encompasses (all or most) White communities scattered throughout Namibia and South Africa, with Gauteng as a historical norm focusing centre (Raidt 1985:321-323). How far has reduced exposure to Standard Afrikaans in Namibia brought about local dynamics of destandardization conducive to divergence from the South African varieties encompassed in those continua? Answering this question involves determining how the new social factor constituted by the political border interacts with ethnic factors, and how this interaction may or may not be in the process of bringing about a new linguistic boundary.

\section{Hypotheses regarding Namibian Afrikaans}

The Milroys (1985) have established that higher mobility - correlated with weak network ties - can encourage parallel dynamics of variation in the speech of central social classes irrespective of geographical location, whereas lower mobility - correlated with strong network ties - will contribute to the maintenance of localized speech norms. An implication is that varieties in use with central social classes will be less likely to display regional variation than varieties in use with lower social classes. If, irrespective of strength of network ties, ethnicity is a defining characteristic of social networks, it follows that ethnically contrasted patterns of sociolinguistic variation are allowed to reproduce themselves across vast 
geographic areas. Evidence in this regard is found in North America, in what seems to be geographically underdetermined distance between African American Vernacular English (AAVE) and vernacular Anglo American varieties: The common core of AAVE grammatical features shared across distant urban locations as well as indications that some urban Black communities have not participated in dynamics of sound change affecting neighbouring Anglo American communities has led to the claims that "urban Vernacular Black English [is] pretty similar from one city to the next" and that AAVE and Anglo American varieties are diverging countrywide (cf. Rickford 1992:262; Labov 1994:157).

Considerable counterevidence has been presented for the claims that social network ties play a more defining role in the diffusion of variation than do geographical factors. This counterevidence is grounded in the observation that physical proximity between different varieties may lead to local contact-induced change unconstrained by the configuration of social networks. This is illustrated by those trends of "contrahierarchical diffusion" from rural to urban areas reported in Oklahoma by Bailey (1993, in Britain 2002:626-627) and in East Anglia by Trudgill (1986, in Britain 2002:626-627). The degree to which ethnic divides in society are reflected in sociolinguistic variation also seems to be sensitive to local circumstances. In this regard, it has been found that some Black American communities do not participate equally - rather than not at all - in linguistic change affecting neighbouring Anglo varieties (Fought 2002:458, 462-465).

It follows from the cases described above that social network ties and geographical factors may override each other or operate conjointly as factors of variation, but no mention has yet been made of linguistic factors by which they may be constrained or stimulated. In this regard, there seems to be some agreement that certain language components may be affected more than others by social or geographic variation. Labov (1994) treated sound changes as associated with local identity and prestige, and grammatical variables as more generalized resources. Rickford (1992) rejected this distinction by adducing cases of grammatical variables strongly associated with local communities and phonological ones that seem to form general resources.

On the basis of the discussion above, three hypotheses can be formulated regarding convergence and divergence of Afrikaans grammatical varieties within and across Namibia's borders. The two hypothetical varieties of which we make mention here are "White Namibian Afrikaans" and "Coloured Namibian Afrikaans", with the latter referring to speech varieties commonly used by the groups formerly labelled "Coloureds" and "Basters" (cf. section 4).

\section{Hypothesis 1}

The White Namibian Afrikaans and Coloured Namibian Afrikaans grammatical varieties are both evolving away from their South African counterparts as a result of underexposure to Standard Afrikaans in Namibian society. The political border is therefore assuming the trappings of a linguistic boundary, dividing the White Afrikaans speech community as well as disrupting the Orange River Afrikaans dialect continuum following a process of destandardization away from Standard Afrikaans in Namibia coupled with an increasing sense of Namibian identity.

\section{Hypothesis 2}

The White Namibian Afrikaans grammatical variety is keeping close to its South African counterparts while the Coloured Namibian Afrikaans grammatical variety is evolving away 
from its Northern Cape Coloured Afrikaans counterparts. This hypothesis follows from the prediction that, on account of their higher socio-economic status, Namibian Whites are more mobile across the border than are Namibian Coloureds/Basters, which enables them to participate in South African social networks and identify with their linguistic norms of which Standard Afrikaans is still a basic component while Namibian Coloureds have less opportunity to identify with South African norms at large and are thus more affected by decreasing exposure to prescriptive Standard Afrikaans ${ }^{6}$. In other words, the political border is assuming the trappings of a linguistic boundary more for Namibian Coloured than for Namibian White Afrikaans speakers.

\section{Hypothesis 3}

Afrikaans grammatical norms adhered to by South African Coloureds and Whites are identified with by Namibian Coloureds and Whites respectively, resulting in uninterrupted convergence with those norms across the border. The emergence of a Namibian spatial dimension is more likely to have an effect on phonology and lexicon. This hypothesis follows from Labov's prediction mentioned above that grammatical variables are general resources less likely to display local variation.

Determining which hypothesis holds true cannot only provide an answer to the question as to whether or not there exists a grammatical variety or varieties of Namibian Afrikaans, it can also provide a case in point on the interaction between human geographic factors and socioethnic variation in grammatical systems.

\section{The corpus}

Two samples, i.e. a White sample ("Nam Wh") and a Coloured/Baster ${ }^{7}$ sample ("Nam Col") comprising close to 55,000 words were collected in Windhoek. Each sample is comprised of roughly equal numbers of males and females and can be broken down in three age cohorts $(17-25,25-50,50+)$. The recruitment of informants mostly followed the "friend of a friend" approach (Milroy 1987) but recordings from chat shows hosted by community radio stations were sometimes added in order to expand the categories 25-50 and 50+ of the White sample. Except for the category 17-25, care has been taken to select individuals representative of the median household income of their area of origin, i.e. the areas of Academia, Eros, Pionierspark and Suiderhof for the White sample, and Khomasdal for the Coloured/Baster sample. Informants falling in the category 17-25 were recruited on the UNAM campus for the Coloured/Baster sample and in the last grade of Windhoek High School for the White sample. Since the guideline for data collection was to minimize the Observer's Paradox in order to obtain a representative picture of spontaneous speech in intra-group communication, the task of interviewing was left to insiders sharing the ethnic and geographic background and age range of the informants. Informal group recordings were particularly successful in producing large amounts of unmonitored informal data, but sometimes also an uncontrollable number of participants (altogether 170) who uttered highly variable numbers of words.

The selection of South African control samples was guided by the aim of confirming or disconfirming the postulated connection between Coloured Namibian Afrikaans and Northern Cape Afrikaans, on the one hand, and between White Namibian Afrikaans and Eastern Afrikaans, on the other. One Coloured sample was recruited from the town of Upington ("SA Col"), located right across the Namibian/South African border in a region usually described as home to the Orange River Afrikaans variety ("ORA"). A White sample was recruited from the 
Gauteng region ("SAWh") in reflection of the fact that the highest concentration of White Afrikaans speakers is located in that region, which is encompassed in the so-called Eastern Afrikaans zone (cf. map 1). The selection of informants also followed the "friend of a friend" approach with recordings from chat shows hosted by community radio stations sometimes being added in order to expand the categories 25-50 and 50+ of the White sample. The 17-25 Coloured age cohort was recruited from the last grade of AJ Ferreira High School in Upington, and the 17-25 White age cohorts from the campuses of the University of Pretoria and of the University of Johannesburg. The South African control samples comprise a total of 143,000 words and 201 speakers.

One of the most striking differences between the sociolinguistic settings of the Namibian and South African samples concerns the younger generations' exposure to prescriptive Standard Afrikaans. Whereas no Namibian informant of the category 17-25 has had Afrikaans as the sole medium of education throughout their school curriculum, most South African informants have. Also, the position of Standard Afrikaans in Upington in general is still strong and unchallenged by English.

Map 1. Location of samples versus established dialect boundaries

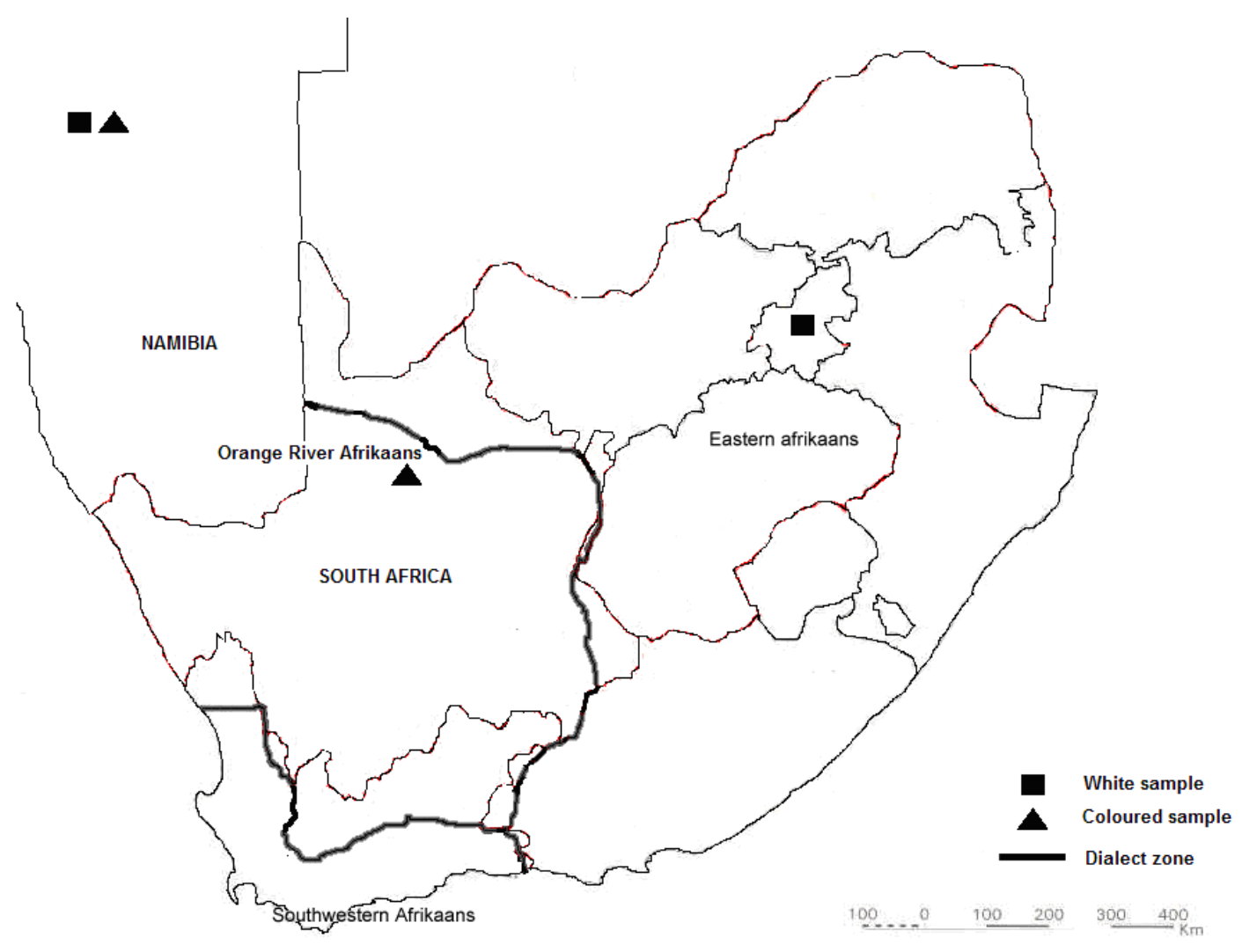

\section{Grammatical variables investigated in this study}

A set of grammatical variables has been singled out for analysis, i.e. (i) four stereotypical ORA morphological variables in the form of the non-standard plural possessive pronouns onse/ons se and hulle se versus standard ons and hulle, irregular past participle formation of verbs with an atonic prefix and irregular past participle formation with double infinitives, (ii) non-standard single versus standard double negation, (iii) invariable versus inflected modal 
auxiliaries (kan, moet, wil vs. kon, moes, wou) + main verb in the past indicative, and (iv) non-standard Verb Second versus standard Verb Final in dependent word order.

Just as the set of ORA morphological features, the single negation is presented in literature as characteristic of the ORA zone. The other two, on the other hand, are not usually characterized in geographic or ethnic terms.

This selection followed from two purposes. The first purpose was to geographically and ethnically characterize the ORA continuum described in literature on the basis of the occurrence of typical ORA features. The second purpose was to test the diffusion across spatial and ethnic divisions of features assumed to occur across the whole Afrikaans speech community.

Below, a historical account is given for each feature. On the basis of available historical clues, a general prediction is made as to where the highest concentrations of each feature can be found.

\subsection{ORA morphological features}

A number of non-standard Afrikaans features are usually presented as characteristic of Coloured varieties from the ORA zone. Among these, we find the use of possessive pronouns adjoined with the clitic particle se, as in onselons se (Std. Afrikaans ons 'our'), julle se (Std. Afrikaans julle 'your-PLURAL') and hulle se (Std. Afrikaans hulle 'their') (Ponelis 1993:230). The irregular formation of the past participle for verbs with an atonic prefix (e.g. ge-vertel 'told' instead of the standard form vertel) or with double infinitives (1) has been described as characteristic of both ORA and Southwestern Afrikaans zones (van Rensburg 1989:147).

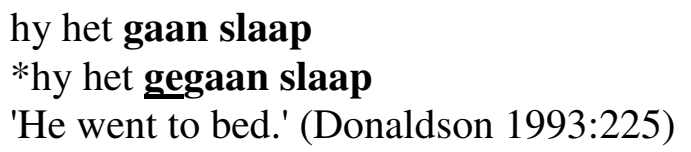

The origin of possessive pronouns with clitic forms as well as of irregular past participle formation has been sought in the Cape Khoi-San substrate. It has been postulated that the insertion of the clitic form se between the personal/possessive pronoun and the possessed object could be a reflexion of the Hottentot use of the particles $\tilde{a}$ and $d i$ as in the examples quoted by Le Roux (1923:98): ti di khóin (literally 'I 's friends'), sa di hãb ('you's horse'), //ěib di ómi ('he's house'). The strong representation of irregular ge-prefixes in the ORA zone has been explained by Roberge (1996:73-75) also as a result of Khoi-San influence, by which gewas by analogy with the Khoi-San particles $g e, g o, g a$ used as a tense marker without the aid of the Dutch tense auxiliary, as attested by sentence (2).

Baas hulle hom geroep die galbôom

Master they it call the gall-tree (Den Besten 2001:15)

Possessive pronouns with clitic particles as well as irregular past participle prefixes are historically not only attested in the ORA zone. Hulle se/zyn could also be found in Cape Malay manuscripts from the late $19^{\text {th }}$ century, while ons zyn/onse was formerly widespread in White speech before falling in disuse (cf. Stell 2007; Malherbe 1917:95; Donaldson 1993:140). Except for ons zyn/onse, a colour stigma seemed to be attached to these clitic particle constructions, as was reported by Von Wielligh (1925:182) for the Northern Cape, 
where according to him only "backward" Whites were likely to use them. The generalization of the ge-prefix knew no geographic or ethnic boundary, and seems to have had a less strong colour connotation than possessive pronouns with clitic particles, as it was widely attested in the late $19^{\text {th }}$ and early $20^{\text {th }}$ century Cape Coloured and White press (Pheiffer 1996:151-152; Raidt 1992:304). This could explain why Donaldson (1993:270, 275) presents this feature as characteristic of a 'very colloquial Afrikaans' without any ethnic or geographic specification.

We expected these features to be mostly represented among Coloured speakers. Another expectation was that features for which a Khoi-San origin has been argued would be better represented on the Namibian side of the border on account of the fact that exposure to KhoiSan languages is still high among local Coloureds/Basters. Our original hypotheses regarding their generational diffusion were quite indefinite. Would their frequencies be found to increase across generations as a result of diminished exposure to Standard Afrikaans? Would they possibly be found to re-emerge in White samples in certain circumstances? Or would they be found to decrease as a result of enduring stigmatisation?

\subsection{Single negation}

Standard Afrikaans uses a brace negation consisting of a first "middle field" negator nie (socalled nie-1) or a negative adverb (geen 'no', niemand 'nobody', nooit 'never') and a clausefinal negator nie (nie-2), as exemplified by sentence (3) below. Use of nie-2 is optional after clause-final negative adverbs as exemplified by sentence (4). Its omission after clause-final nie is obligatory. Nie-2 as a scope marker can negate entire sentences (simplex and complex) as well as sentence constituents.

(3) Jan staan nie elke oggend vroeg op nie.

'Jan does not get up early every morning.' (van Schoor 1983:340)

Sy rus nooit (nie).

'She never rests.' (van Schoor 1983:337)

A number of theories have been advanced to locate the origin of the Afrikaans brace negation. Waher (1994) is of the opinion that dialectal Dutch patterns of double negation may have been a factor in the appearance of nie-2, whose clause-final position would form the endresult of a clause-wide rightward shift of constituents leaving traces of their original location. For Den Besten (1989:241), the origin of nie-2 is rather to be sought in those Hottentot sentence-final negators tama (indicative) and tite (future) which bear the focus of negation, but this idea was challenged by Ponelis (1993:470-472), who argued that the negators in Nama are not strictly sentence-final, and can be moved to the left. Also, nie-2 is not attested in the corpus of early Khoe and Slave Cape Dutch (Den Besten 1986:205). Whether or not the substratalist interpretation is well-founded, it seems that the use of the brace negation had a distinct ethnic correlation: White Cape Dutch writers had not generalized nie-2 at a time when double or treble negation was hegemonic in Cape Malay writings (cf. Deumert 2004:204; Stell 2007). In other terms, the brace negation may have been predominantly used by nonWhites. Surprisingly, this probability does not seem to be corroborated by current data.

Nowadays, nie-2 seems to be generalized in White colloquial speech whereas ORA is said to rather use a single than a double negation (cf. Feinauer 1994:96; van Rensburg 1989:147). On the basis of these observations, one may expect instances of single negation in our corpus to occur primarily in the Coloured samples from Namibia and Upington, and more marginally or not at all in the White samples. 


\subsection{Past form of modal auxiliaries + main verb in the past indicative}

Afrikaans uses more contextual than formal means to operate a distinction between its tenses and moods. Beside the tense auxiliaries hê 'to have' and wees 'to be', the modal auxiliaries kan 'can', moet 'must', sal 'shall/will', wil 'to want', and mag 'may' are the only verbal forms which can be inflected (into respectively kon, moes, sou, wou and archaic mog) such as to convey tense and mood distinctions (cf. Donaldson 1993:236-241; Conradie 1994:293). The different configurations in which modal auxiliaries are associated in their inflected or uninflected forms with main verbs in the past tense can be summarized in four types, as indicated in (5) to (8) below:

(5) Type 1: Inflected past modal auxiliary + infinitive, as in:

Hy kon nie kom nie.

'He couldn't come.' (De Villiers 1971:90)

(6) Type 2: het + inflected or uninflected modal auxiliary + infinitive, as in:

Ek het dit altyd kan/kon doen.

'I have always been able to do it.' (Donaldson 1993:241)

(7) Type 3: Inflected modal auxiliary + past participle + het, as in:

Kon jy nie die hek oopgekry het nie?

'Couldn't you have opened/open the gate?' (Donaldson 1993:245)

(8) Type 4: Uninflected modal auxiliary + past participle + het, as in:

My broer kan al by die huis aangekom het; ek gaan net gou seker maak.

'My brother can already have got home; I am just going to check.'

(van Schoor 1983:155)

Type 1 is used primarily in the past indicative, but can be used with an irrealis meaning in the function of expressing wishes (ek wou net vra...'I'd just like to ask') or in conditional clauses, as in (9):

(9) As ek 'n koper kon vind, dan sou ek dit verkoop.

'If I could find a buyer, then I would sell it.' (De Villiers 1971:103).

Type 2 is used in a strictly past indicative meaning, whether or not the modal auxiliary is inflected (Donaldson 1993:241). Types 3 and 4 can convey both a general past indicative and a past conditional meaning, the two of which can in many cases only be distinguished on the grounds of contextual clues (cf. van Schoor 1983:141; Donaldson 1993:240-244).

Prescriptive Standard Afrikaans advocates the combination inflected modal auxiliary + infinitive (e.g. moes doen 'had to do', kon doen 'could do') for expressing the past indicative (van Schoor 1983:145, 154-155; see further de Villiers 1971:94-95).

Information as to the respective diffusion of the four types in the past indicative is scarce, and in all cases not quantified. Referring to his White corpus, Donaldson (1993:241, 245) describes type 2 (het kan/kon doen) as rare and type 4 (kan gedoen het) as "occasional" while remaining unspecific as to the respective diffusion of types 1 and 3. On the other hand, Klopper (1983:288) and Kotzé (1989:260) found a significant representation of type 4 (kan 
gedoen het) with either an irrealis or an indicative meaning in Southwestern Cape Coloured Afrikaans. On this basis, a prediction could be that types 1 and 3 are dominant in the White sample, whereas type 4 could be significantly represented in the Windhoek Coloured sample in reflection of its historical ties with the Western Cape (cf. section 2).

\subsection{Verb Second}

Prescriptive Standard Afrikaans still closely resembles Dutch as far as Verb Second and Verb Final placement in clauses is concerned. However, the placement of verbs in a multi-verb clause is freer in prescriptive Standard Afrikaans: Leftward movement is tolerated in certain syntactic contexts, as in conjunctive clauses without a complementizer (sentence 10), or in "open finals", i.e. verbal phrases involving a verbal or adverbial element closely associated with the verb (sentence 11). On the other hand, Verb Final is obligatory in conjunctive clauses with a complementizer (sentence 12).

(10) Die dokter het ontdek [sy het pes onder lede].

'The doctor found out she contracted pest.'

(11) Die dokter het ontdek [dat sy pes onderlede het]. (Ponelis 1979:441)

(12) Hy het by my kom wegkruipertjie speel.

'He came to play hide-and-seek at mine.' (van Schoor 1983:167)

There is a tendency in spoken Afrikaans, condemned by purists, to favour Verb Second over Verb Final (cf. Ponelis 1993:340-343; Biberauer 2003:37-39), as in (13).

?Ek glo [dat dit is besig om uit te sterf].

'I believe this is in the process of dying out.' (Carstens 2002:48)

By far the most common interpretation in literature is that of recent grammatical convergence with English, which could explain why clear-cut cases of Verb Second are hard to find in written material from the time preceding the British period (Ponelis 1993:341-342). According to den Besten (1989), however, there could have been a conflict between Verb Final in dependent word order/SOV and Verb Second in dependent word order/SVO from the earliest stages of Cape Dutch on account of the opposition between the divergent substrates in presence, namely the Hottentot SOV substrate, and the SVO Creole Portuguese and Malay substrates. Credible evidence for that hypothesis is found in the fact that Cape Malay manuscripts from the late $19^{\text {th }}$ century, which represent the variety most influenced by the Creole Portuguese and Malay substrates, show a widespread tendency for Verb Second in a socio-cultural context where this syntactic pattern could hardly have been caused by English influence (Stell 2007).

On the grounds of the above interpretations, a plausible expectation could be that Verb Second occurs primarily in the White sample from Gauteng, i. e. the sample historically most exposed to English. In contrast, the Windhoek White and the Coloured samples could be expected to show more compliance with prescriptive Standard Afrikaans as a result of less historical exposure to English, as well as influence from the SOV Khoi-San substrate in the case of the latter. 


\section{Distribution of grammatical variables in the corpus}

Two methods of calculation have been implemented to assess the distribution of features in each age cohort. For low frequency variables (i.e. the plural possessive pronouns, invariable versus inflected modal auxiliaries + main verb in the past indicative), only binomial distributions (i.e. proportions of speakers using a given feature versus proportions of speakers not using the feature) are calculated. As regards high frequency variables (negation, position of verb in subordinate clauses), age cohort frequencies are calculated on the basis of the frequencies of a given variable per speaker (only when at least five occurrences are present). The analysis conducted in this section only takes age range as a social variable, thus leaving gender out of consideration. One reason for this is that the "friend of a friend" approach in sampling often yielded exchanges involving both genders in interaction, thereby compromising the possibility of obtaining a picture of gender varieties as representatively contrasted as that for age cohort varieties. The possible impact of gender has nonetheless been tentatively reconstructed in section 7 , on the basis of the distribution across genders of the high frequency variables negation and position of verb in subordinate clause.

\subsection{ORA morphological features}

But for one exception, our basic assumption that ORA morphological features would be most represented in the Coloured samples was confirmed. The diffusion of features across generations shows a contrasted picture across samples.

In the Northwestern Coloured sample, all features except one (namely irregular ge- with double infinitives) are in decline (fig. 1). Interestingly, the latter feature temporarily subsides among middle-aged speakers to re-emerge among younger speakers.

Fig. 1. Diffusion of non-standard "ORA features" vs. standard equivalents in the Northwestern Coloured sample (\%, present/non-present)

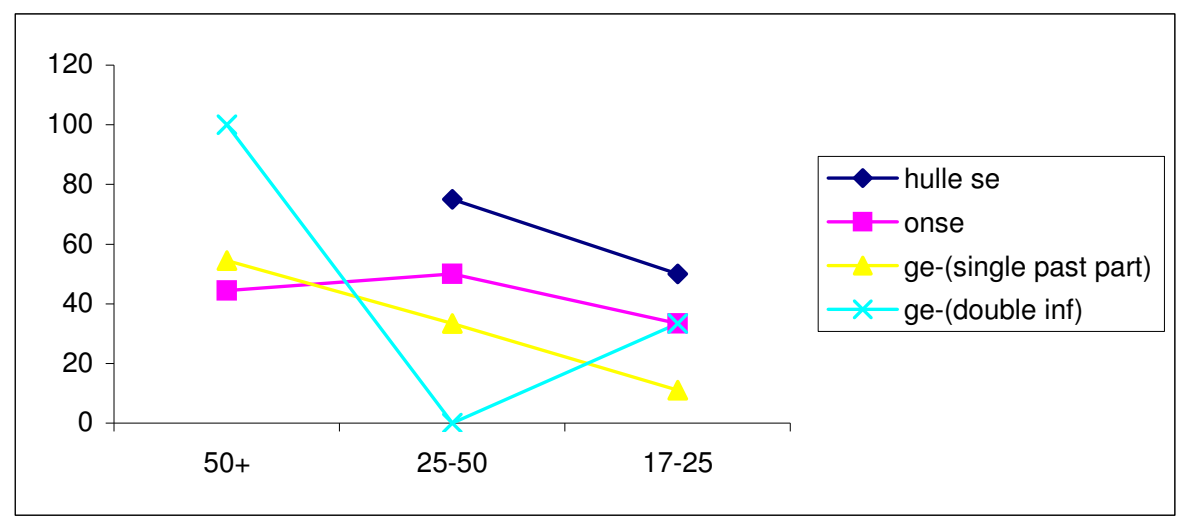

Data from older speakers of the Namibian sample (fig. 2) were unfortunately too scarce to infer whether the features in question here are generally better represented on the Namibian than on the South African side of the ORA zone. However, one feature for which data were sufficient across all generations, i.e. onselons se, turned out to be better represented among older Namibian Coloured speakers than among older Northwestern Coloured speakers. The diffusion of features among younger generations shows a striking contrast with the 
Northwestern Coloured sample in that they are all expanding after a temporary decline among middle-aged speakers.

Fig. 2. Diffusion of non-standard "ORA features" vs. standard equivalents in the Namibian Coloured sample (\%, present/non-present)

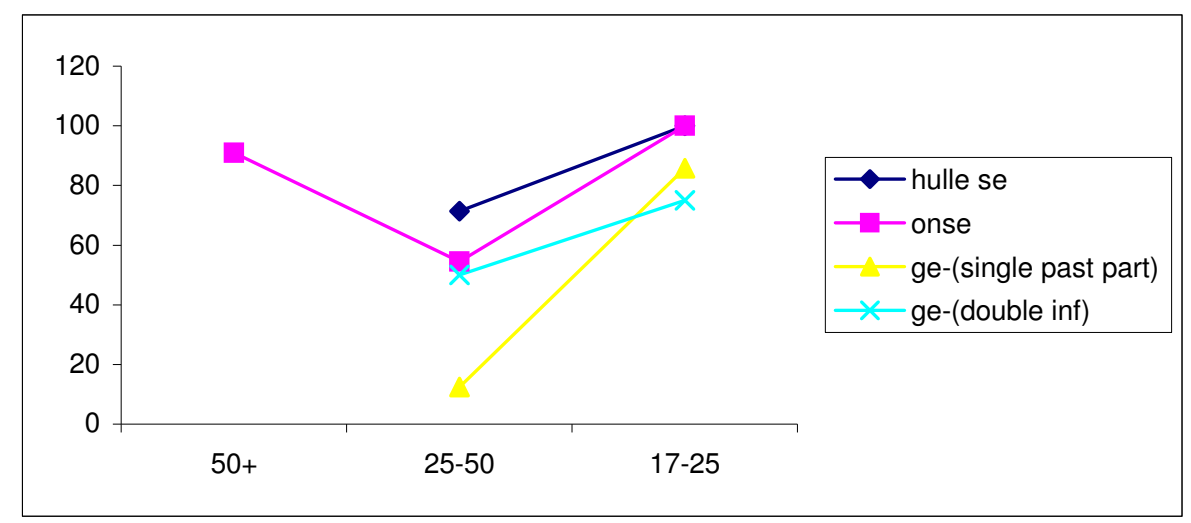

Finally, the only White sample in which one of the features in question here is significantly represented, i.e. the White Namibian sample, musters a high frequency for irregular ge- with double infinitives among older speakers, but this frequency sharply decreases from older to middle-aged speakers, and the feature is totally absent among younger speakers.

On the basis of the above observations, the inference can be made that a former state of linguistic cross-border continuum involving Coloureds and, to a lesser extent, Whites could be in the process of being disrupted with Upington Coloureds and Namibian Whites moving closer to prescriptive Standard Afrikaans.

\subsection{Single versus Double Negation}

While searching the corpus for instances in which nie-2 is omitted, those cases where nie-2 is considered optional have been left out of consideration. Figure 3 shows that the distribution of the non-standard single negation across generations is more or less parallel across the Coloured samples, whereas it is not in the White samples. As regards the Coloured samples, frequencies decrease from the older to the middle-aged cohorts, after which they seem to stabilize in the younger cohorts. In the White samples, frequencies in the older cohorts are higher in the Namibian sample than in the Gauteng sample, but frequencies for both samples join up with each other in the younger cohort. Differences between younger cohorts across the whole corpus are relatively small. There is a growing proportion of speakers using the feature in all samples. 
Fig. 3. Distribution of single versus double negation

$(\%, \mathrm{~N}=1774)$

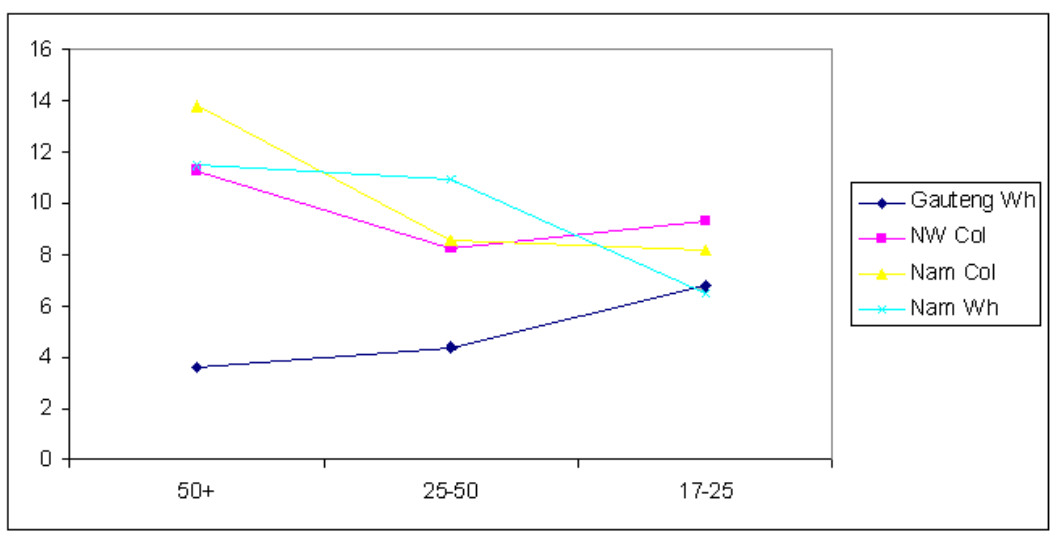

Worth mentioning is that frequencies for the older White cohort from Windhoek are almost identical to those for older Coloured cohorts from Windhoek and Upington, which may point to a former state of continuum between White and Coloured varieties within the ORA zone.

\subsection{Past form of modal auxiliaries + main verb in the past indicative}

In order to measure the diffusion of all four types of modal auxiliaries + main verb in the past indicative (cf. section 5.3) across the Afrikaans speech community, the corpus has been searched for inflected or uninflected occurrences of the modal auxiliaries kan, moet and wil associated with a main verb, of which the semantic content could contextually be ascertained as indicative rather than conditional. Occurrences of mag + main verb have been discounted as the variation between the uninflected form mag and the archaic inflected form mog proved totally absent. To reduce the chance for conditional contents to slip through, no account has been taken of conditional clauses and polite requests of the type ek wou net gou vra ('I'd just like to ask'). Since type 2 (het + inflected or uninflected modal auxiliary + infinitive) did not occur at all, only the distributions of types 1 (inflected past modal auxiliary + infinitive), 3 (inflected modal auxiliary + past participle + het) and 4 (uninflected modal auxiliary + past participle + het ) have been taken into account.

Figures 4 to 6 show that the proportions of White speakers using type 1 (e.g. kon doen) increase more or less gradually from the older to the younger age cohorts. They decrease among Upington Coloured after reaching a peak among middle-aged cohorts. Type 1 is, by contrast, not represented at all among middle-aged and younger Windhoek Coloured speakers. The proportions of White speakers using type 3 (e.g. kon gedoen het) remain more or less stable across all three age cohorts of the White samples, while they sharply decrease in the Coloured samples after a peak reached among middle-aged speakers from Upington. Comparing figures 5 and 6 , it seems that much of the ground lost by type 3 in the Coloured samples has been reclaimed by type 4 (e.g. kan gedoen het), which is present among an expanding proportion of speakers. 
Fig. 4. Distribution of type 1 (kon doen) vs. other types $(\%, \mathrm{~N}=336)$

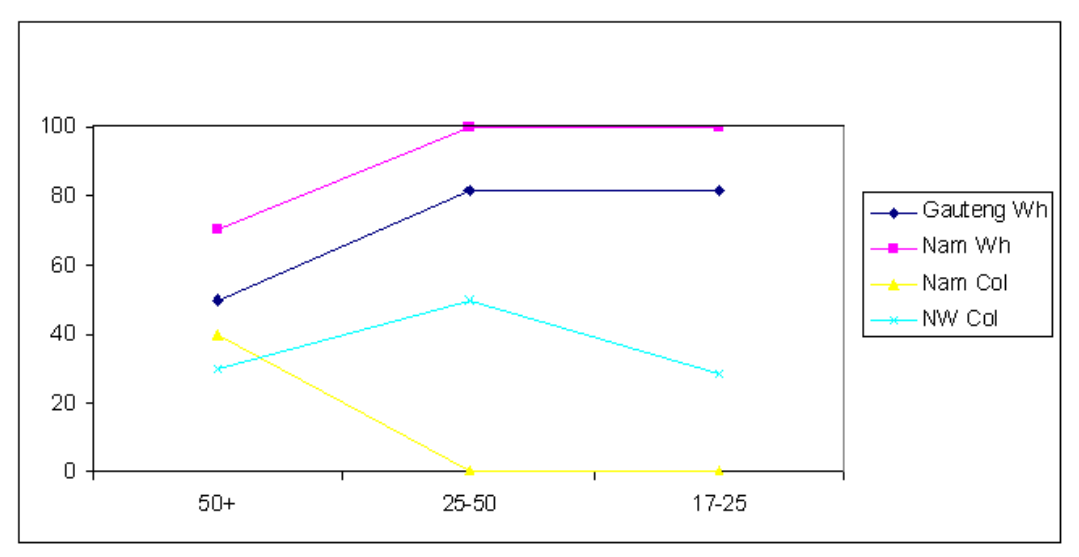

Fig. 5. Distribution of type 3 (kon gedoen het) vs. other types

$$
(\%, \mathrm{~N}=336)
$$

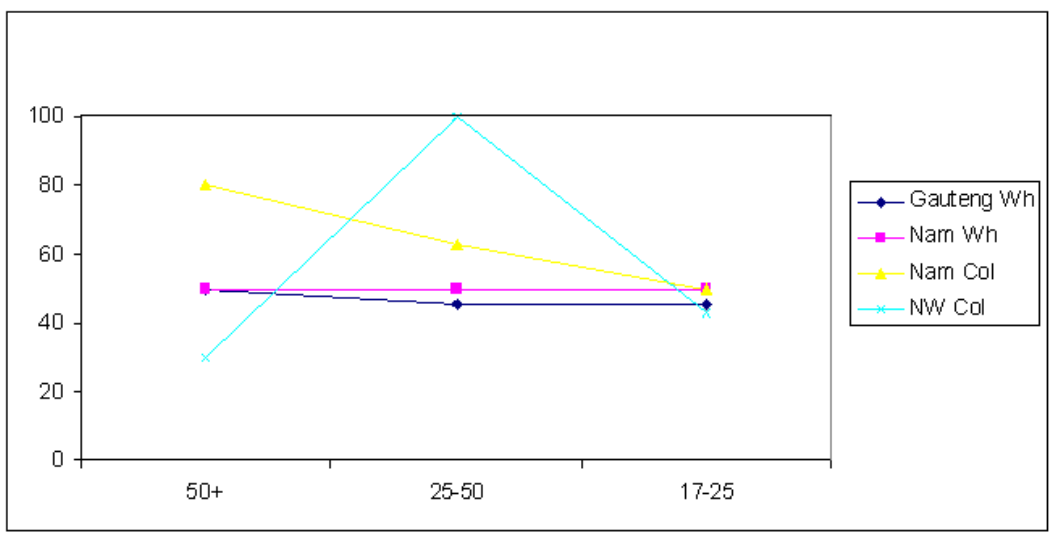

Fig. 6. Distribution of type 4 (kan gedoen het) vs. other types

$$
(\%, \mathrm{~N}=336)
$$

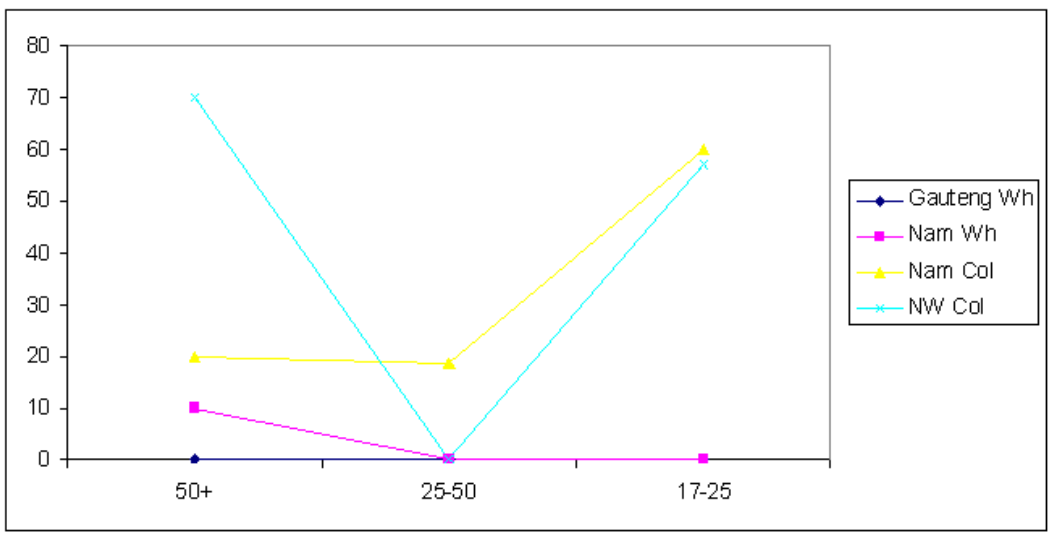


An explanation for the dynamics of variation in the Coloured samples could be as follows: Type 1 (e.g. kon doen) may be perceived as formal, and the decreasing exposure to prescriptive Standard Afrikaans among Windhoek Coloureds may have led to its demise. Type 3 (e.g. kon gedoen het) could be a hypercorrect rendition of type 4 (e.g. kan gedoen het), which is used by older and middle-aged cohorts in reflection of White norms of usage where type 3 is the main alternative to type 1. Decreasing prestige of White norms could have paved the way to the restoration or expansion of type 4.

The idea of a Coloured continuum within the ORA zone can be illustrated here with the gradually decreasing frequencies for type 3 (e.g. kon gedoen het) in the Namibian and Upington samples. The idea of a continuum within the ORA zone involving both Coloured and White varieties can be illustrated with the observation that older White and Coloured Namibian speakers use Type 4 (e.g. kan gedoen het) before that feature subsides in the White sample.

\subsection{Verb Second versus Verb Final}

The corpus has been searched for clear-cut cases of Verb Second in dependent order, and no account has therefore been taken of structures which could be either Verb Second or Verb Final by want of a centre position and a pivot verb. Also, no account has been taken of subordinate clauses in which the non-verbal material consists of nothing but elements which are allowed to move to the end zone in terms of prescriptive Standard Afrikaans (e.g. prepositional complements, as opposed to direct objects which by default must occur in the centre position, cf. Ponelis 1979:518-522, 1993:311-313). Cases such as (14) have been treated as instances of Verb Second rather than as open finals on the grounds that the nonverbal element in the centre position (i.e. arrogant) does not form part of an acknowledged separable verb as does e.g. skoolgaan 'to go to school'.

(14) [As jy beginne V arrogant Adj raak V], dan het hulle volste reg om vuur by mekaar te maak.

'If you start getting arrogant, then they are fully entitled to making your life hard.'

Figure 7 shows that clear-cut cases of Verb Second are increasing in the Gauteng, Upington and Windhoek Coloured samples while remaining stable across all three age cohorts of the Windhoek White sample. While the increase from older to younger speakers is gradual in the Namibian samples, it shows an interruption in the South African samples. Generally, frequencies in the Coloured samples are much higher than those in the White samples. 
Fig. 7. Distribution of Verb Second versus Verb Final

$(\%, \mathrm{~N}=1374)$

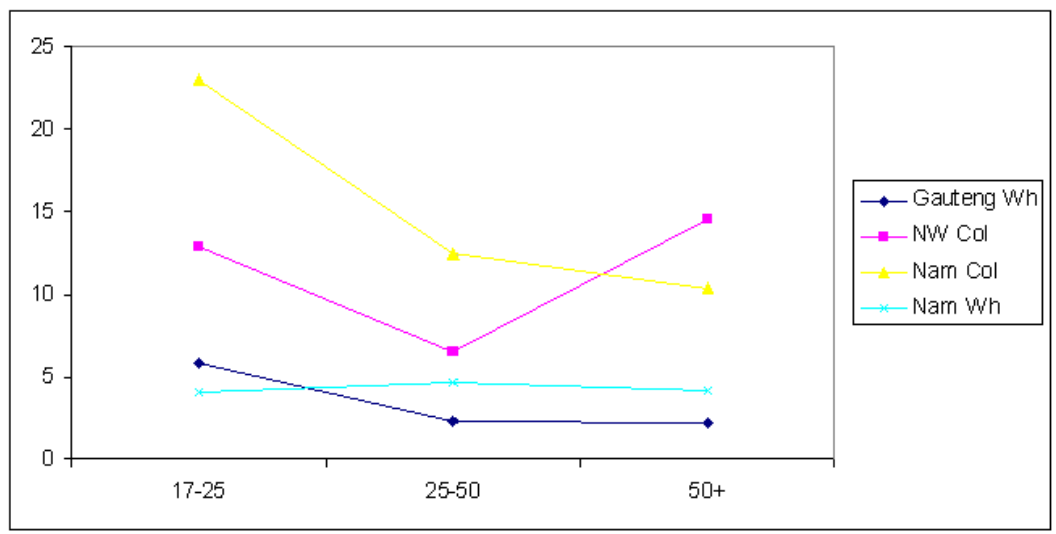

The existence of a continuum involving Coloured varieties across the border seems to be confirmed by the comparably high frequencies of Verb Second among older and younger Coloured speakers from Windhoek and Upington. There is a geographic opposition between South Africa and Namibia - in which ethnicity does not seem to be a factor - in the observation that standardization towards Verb Final has had a greater effect among middleaged Gauteng Whites than among middle-aged Namibian Whites. The historically grounded expectation that Verb Final may be better represented in Namibia and Upington is not confirmed by the data (cf. section 5.4). The proportion of speakers using Verb Second is growing in the Coloured samples, and decreasing in the White samples.

A breakdown of V2 clauses (with overt complementizers only) shows that dat-clauses are most likely to have V2, followed by $w$-clauses and other clauses (cf. Table 1), which confirms Biberauer's (2002) findings on modern spoken Afrikaans in general. Clearly, dat-clauses in the Coloured samples are more likely than in the White samples to have V2. The nature of the V2 verb (mainly functional) as well as of the matrix verb (mainly verba sentiendi et dicendi) further corroborate the author's findings without any opposition being visible between Coloured and White or South African and Namibian samples.

Table 1. V2 per clause type (\%)

\begin{tabular}{|l|c|c|c|c|}
\hline \%V2 & NWhU & NAWh & NAC & NWC \\
\hline Dat & $17 \%$ & $6.84 \%$ & $31.81 \%$ & $34.04 \%$ \\
\hline W & $5 \%$ & $4.7 \%$ & $5.95 \%$ & $2.94 \%$ \\
\hline Others & $2.32 \%$ & $0 \%$ & $9.67 \%$ & $0 \%$ \\
\hline
\end{tabular}

\section{Discussion}

The results of the analysis above provide evidence for an ethnic divide opposing Coloureds and Whites irrespective of geographic division. This ethnic divide is illustrated with the following observations:

- Some features are found exclusively with Coloured speakers, such as hulle se, onse/ons se and irregular past participle formation of verbs with atonic prefixes. 
- Features which are non-standard in terms of prescriptive Standard Afrikaans are more diffused in almost all age cohorts of the Coloured samples. This observation applies to what we called "ORA features", the single negation, type 4 of past indicative form for modal verbs and Verb Second.

- There are some parallel patterns of expansion from middle-aged to younger speakers in the Coloured samples which are not reflected in White samples. This concerns type 4 of past indicative form for modal verbs and irregular past participle formation with double infinitives.

- Transitions from distribution patterns in middle-aged cohorts to frequencies in younger cohorts are more abrupt in the Coloured samples than in the White samples. This could mean either that age grading is stronger among Coloureds or that there is an intergenerational break in grammatical norms that is not paralleled in the White samples.

- Distribution patterns in White samples are converging. This convergence could mean disruption of a former continuum involving Coloured and White Namibian Afrikaans varieties within the ORA zone, as illustrated by the decreasing frequencies of irregular past participle formation with double infinitives and single negations in the latter group.

- Generally, patterns of increase or decrease of proportions of speakers using a given feature co-vary with ethnicity.

The above suggests that there is an enduring continuum involving Coloured varieties across the border. Windhoek Whites do not, or do no longer form part of this continuum and seem more closely related in their grammatical patterns to their peers from Gauteng. There are, however, some suggestions that the Coloured continuum within the ORA zone is being disrupted by the border, which can be inferred from the following observations:

- Some features which are expanding among Windhoek Coloureds are actually losing ground among Upington Coloureds, such as hulle se and onse/ons se.

- Some standard features which are losing ground among Windhoek Coloureds are maintained among Upington Coloureds. This concerns type 1 of past indicative form for modal verbs in particular.

This indicates that younger Windhoek Coloureds are diverging from prescriptive Standard Afrikaans whereas Upington Coloureds are not. Discontinued exposure to prescriptive Standard Afrikaans on the Namibian side may thus be driving a permanent linguistic wedge between these two Coloured communities.

Regardless of exposure to prescriptive Standard Afrikaans, some non-standard features could be expanding in the Namibian Coloured sample as a result of growing prestige, as well as of the growing need of marking an identity defined in ethnic terms. This could particularly be the case with pronouns with clitic particles, single negation and type 4 of past indicative form of modal verbs, which tend to systematically co-occur in the Coloured samples. The idea of prestige being associated with these non-standard features in the Namibian Coloured sample could be reflected in the observation that such features are relatively overrepresented among young female speakers, whereas young male speakers show themselves to be more conservative ${ }^{8}$. The view that continued or discontinued exposure to prescriptive Standard Afrikaans may be playing a more limited part than ethnic identity marking in the diffusion of variation is corroborated by trends in the Upington 
sample, where continued exposure to Standard Afrikaans does not stop certain standardization trends observable from older to middle-aged speakers from being reversed among young speakers. A difference between this sample and the Namibian Coloured one is, interestingly, that it is not among young female speakers but among young male speakers in the Upington sample that non-standard features are most represented, which could indicate that the prestige locally attributed to these features is more covert. Following the same logic of ethnic identity marking, some features expanding in the Windhoek Coloured sample seem to be falling out of use in the Windhoek White sample despite the sociolinguistic settings being similar for both samples. In the Windhoek White sample, features expanding from middle-aged to younger speakers are relatively overrepresented among younger female speakers, whereas their peers from Gauteng seem to be more conservative. Given the convergence between Windhoek and Gauteng Whites, this observation could suggest that Windhoek Whites attach more prestige to White South African norms than to the abstract Standard Afrikaans school norm.

White Afrikaans speakers form one focused speech community and the political border does not affect the process of convergence visible between the Windhoek and Gauteng White samples. The same applies, to a lesser degree, to the Coloured samples: Parallel trends in them suggest the continued existence of a Coloured speech community with a shared pool of features. However, the border seems to act as a factor of divergence between Namibian and Northern Cape Coloureds by favouring destandardization away from prescriptive Afrikaans on the Namibian side. As such, the predictions of hypothesis 2 (cf. section 2) are borne out by the corpus data. This means, in the context of sociolinguistic variation in the Afrikaans speech community, that ethnicity coupled with high mobility is a more potent factor of speech variation than space, and conversely, that space is more potent than ethnicity as a factor of speech variation when ethnicity is coupled with low mobility. On the basis of our findings, the answer to our original question, namely whether there is a Namibian Afrikaans, is that evidence for it at the grammatical level is still sparse as a result of ethnic networks transcending the border still being close-knit.

\section{Notes}

1. The labels "Coloured" and "Baster" are not universally accepted by the persons concerned. These labels are employed here in a historical sense. The label "Coloured" is still in official use in South Africa, whereas "Baster" is not.

2. Even though Afrikaans became an official language of South Africa in 1925, it had already been in the process of replacing Dutch in education in the preceding years (Ponelis 1993:54).

3. Official censuses commissioned after Independence do not take account of population groups formerly defined under the Apartheid regime. The most recent data taking account of the categories "White", "Coloured" and "Baster" are those published in Prinsloo (1982).

4. Cf. van Rensburg (1989:438-439) and Ponelis (1993:13-15) for the taxonomy of Afrikaans dialects. See further Grebe (1997) for a discussion on the regional and ethnic representativeness of that taxonomy.

5. The label "Standard Afrikaans" as we use it refers to the prescriptive variety exemplified by reference sources as didactic materials used in education. We are therefore not using "Standard Afrikaans" in its relatively new Hallidayan meaning of 
most commonly comprehensible and widespread variety of Afrikaans (cpr. Vandenberg 2000:240).

6. The prediction that Namibian Whites are more mobile than Namibian Coloureds is based on South African statistics on ethnicity and income levels as well as statistical observations on ethnicity and geographic mobility made in South Africa in 1984 and 2004 (cpr. Statistics South Africa 2003; Kok et al. 2003:55, 63). As previously observed, no statistical information correlated with ethnicity is available from postIndependence Namibian censuses.

7. Maintaining the distinction between "Coloureds" and "Basters" proved difficult in practice as the two labels do not seem to refer to discrete social networks in the urban context of Windhoek/Khomasdal. Therefore Coloured and Baster informants were grouped as one single category for the purposes of this research.

8. The equation between linguistic prestige and linguistic features overrepresented among women rests upon Labov's (1990, in Cheshire 2002:425-6) principles according to which "women favour the incoming prestige forms more than men" and "women are most often the innovators".

\section{References}

Beuke, C. 1997. Afrikaans in Namibië: Kontak en konflik. In W. De Geest (ed.) Recente studies in de contactlinguïstiek. Bonn: Dümmler. pp. 1-7.

Biberauer, T. 2002. Verb Second in Afrikaans. Is this a unitary phenomenon? Stellenbosch Papers in Linguistics 34: 19-70.

Britain, D. 2002. Space and spatial diffusion. In J.K. Chambers, P. Trudgill and N. SchillingEstes (eds). The handbook of language variation and change. London: Blackwell. pp. 603-637.

Carstens, W.A.M. 2002. Norme vir Afrikaans. Enkele riglyne by die gebruik van Afrikaans. Pretoria: Van Schaik.

Cheshire, J. 2002. Sex and gender in variationist research. In J.K. Chambers, P. Trudgill and N. Schilling-Estes (eds). The handbook of variation and change. London: Blackwell. pp. 423-443.

Combrink, J.G.H. 1984. Afrikaans in Afrika. In K.P. Prinsloo and M.C.J. van Rensburg (eds). Afrikaans: Stand, Taak, Toekoms. pp. 43-58.

Conradie, C.J. 1994. Het modale hulpwerkwoord: Gebruiksverschillen tussen het Nederlands en het Afrikaans. Acta Universitatis Wratislaviensis Nr. 1640. Neerlandica Wratislavensia VII. Wroclaw 1994. pp. 291-300.

De Villiers, M. 1971. Die grammatika van tyd en modaliteit. Cape Town: Balkema.

Den Besten, H. 1986. Double negation and the genesis of Afrikaans. In P. Muysken and N. Smith (eds). Substrata versus Universals in Creole Genesis. Papers from the Amsterdam Creole Workshop, April 1985. Amsterdam: Benjamins. pp. 185-230.

Den Besten, H. 1989. From Khoekhoe foreignertalk via Hottentot Dutch to Afrikaans: The creation of a novel grammar. In M. Pütz and R. Dirven (eds). Wheels within wheels. Papers of the Duisburg Symposium on Pidgin and Creole Languages. Duisburger Arbeiten zur Sprach- und Kulturwissenschaft. Frankfurt am Main: Peter Lang. pp. 207-249.

Den Besten, H. 2001. What became of the Cape Dutch pidgin(s)? In B. Igla, N. Boretzky and T. Stolz (eds). Was ich noch sagen wollte. Berlin: Akademisch Verlag. pp. 205-222.

Deumert, A. 2004. Language standardization and language change. The dynamics of Cape Dutch. Impact. Studies in language and society. Amsterdam: Benjamins.

Donaldson, B.C. 1993. A grammar of Afrikaans. Amsterdam: Mouton De Gruyter. 
Du Plessis, H. 1987. Variasietaalkunde. Pretoria: Serva.

Du Plessis, L.T. 1985. Afrikaans afgedwing in SWA/Namibië. South African Journal of African Languages 3(1): 58-61.

Feinauer, I. 1994. Die plasing van nie-1 en nie-2 in die Afrikaanse spreektaal. South African Journal of Linguistics 19: 92-119.

Fought, C. 2002. Ethnicity. In J.K. Chambers, P. Trudgill and N. Schilling-Estes (eds). The handbook of language variation and change. London: Blackwell. pp. 444-472.

Grebe, H. 1997. Die historiografie van Afrikaans in heroënskou. Doctoral Dissertation. University of Pretoria.

Klopper, R.M. 1983. Taalsisteemvariasie in Kaapse Afrikaans. In A.J.L. Sinclair (ed.) G.S. Nienaber. ' $n$ Huldeblyk. pp. 275-296.

Kok P., M. O'Donovan, O. Bouare and J. van Zyl. 2003. Post-Apartheid patterns of internal migration in South Africa. Pretoria: HSRC.

Kotzé, E.F. 1989. How Creoloid can you be? Aspects of Malay Afrikaans. In M. Pütz and R. Dirven (eds). Wheels within wheels. Papers of the Duisburg Symposium on Pidgin and Creole Languages. Duisburger Arbeiten zur Sprach- und Kulturwissenschaft 5. Frankfurt am Main: Lang. pp. 251-264.

Labov, W. 1994. Principles of linguistic change, vol. 1: Internal Factors. Cambridge, MA: Blackwell.

Le Roux, J.J. 1923. Oor die Afrikaanse sintaksis. Amsterdam: Swets and Zeitlinger.

Maho, J.F. 1998. Few people, many tongues. The languages of Namibia. Cape Town: Gamsberg McMillan.

Malherbe, D.F. 1917. Afrikaanse Taalboek. Bloemfontein: Nasionale Pers.

Marais, J.S. 1962. The Cape Coloured people, 1652-1937. Johannesburg: Witwatersrand University Press.

Milroy, J. and L. Milroy 1985. Linguistic change, social network and speaker innovation. Journal of Linguistics 21: 339-84.

Milroy, L. 1987. Language and social networks. Oxford: Blackwell.

Niemand, C.M. 1979. Onderwys aan die swart volke van Suidwes-Afrika tot 1979. M.A. Thesis. University of Potchefstroom.

Ohly, R. 1987. The destabilization of the Herero language. African Studies of the Academy, vol. 2. Windhoek: The Academy.

Pheiffer, R.H. 1996. 'Straatpraatjes'. 'n Vroeë voorbeeld van Alternatiewe Afrikaans. In M. Adhikari (ed.) Straatpraatjes. Language, politics and popular culture in Cape Town, 1909-1922. Pretoria: Van Schaik. pp. 141-162.

Ponelis, F. 1979. Afrikaanse sintaksis. Pretoria: Van Schaik.

Ponelis, F. 1993. The development of Afrikaans. Frankfurt am Main: Peter Lang.

Prinsloo, K.P. 1982. Aspekte van taal- en kommunikasieaangeleenthede in SWA/ Namibië, vol. 1-13. Pretoria: HSRC.

Raidt, E. 1985. Historiese perspektief op die normering van Afrikaans. In E. Raidt (ed.) Historiese Taalkunde, 1994. Johannesburg: Witwatersrand University Press. pp. 311329.

Raidt, E. 1992. Taalvariasie in negentiende-eeuse Afrikaans. In E. Raidt (ed.) Historiese Taalkunde. Studies oor die geskiedenis van Afrikaans. Johannesburg: Witwatersrand University Press. pp. 289-310.

Rickford, J. 1992. Grammatical variation and divergence in Vernacular Black English. Reprinted in J. Rickford 1999, African American Vernacular English. Malden, MA: Blackwell. pp. 112-154. 
Roberge, P. 1996. Multilevel syncretism and the evolution of the Afrikaans periphrastic possessive. Stellenbosch Papers in Linguistics 30: 123-153.

Statistics South Africa. 2003. Census in Brief 2001. Pretoria: Statistics South Africa.

Stals, E.L.P. and F. Ponelis 2001. Só het Afrikaans na Namibië gekom. Windhoek: Gamsberg McMillan.

Stell, G. 2007. From Kitaab-Hollandsch to Kitaab-Afrikaans: The evolution of a non-white literary variety at the Cape (1856-1940). Stellenbosch Papers in Linguistics 37: 89127.

Steyn, J.C. 1980. Tuiste in eie taal. Die behoud en bestaan van Afrikaans. Cape Town: Tafelberg.

Trümpelmann, G.P.J. 1948. Die boer in S.W.A. In Argiefjaarboek vir geskiedenis. $11^{\text {th }}$ issue, part II. Cape Town: Government's printer.

Van der Merwe, J.H. 1983. National Atlas of South West Africa. Goodwood: National Book Printers.

Van Rensburg, M.C.J. 1989. Soorte Afrikaans. In T.J.R. Botha (ed.) Inleiding tot die Afrikaanse taalkunde. Pretoria: Academica. pp. 436-467.

Van Schalkwyk, D.J. and F.F. Odendal. 1987. 'n Sosiolinguïstiese analise van RehobothAfrikaans. South African Journal of Linguistics 5(1): 144-167.

Van Schoor, J.L. 1983. Die grammatika van Standaardafrikaans. Johannesburg: Lex Patria.

Vandenberg, R. 2000. Die konsep Standaardafrikaans:'n kritiese oorsig en Hallydayaanse perspektief. Doctoral Dissertation. University of Potchefstroom.

Von Wielligh, G.R. 1925. Ons geselstaal. 'n Oorsig van gewestelike spraak soos Afrikaans gepraat word. Pretoria: Van Schaik.

Waher, H. 1994. Die dialektiese ontkenning in Afrikaans. In G. Olivier and A. Coetzee (eds). Nuwe perspektiewe op die geskiedenis van Afrikaans. Johannesburg: Southern Books. pp. 102-109. 